Marine Environmental Research

July 2008, Volume 66, Issue 1, Pages 59-61

http://dx.doi.org/10.1016/j.marenvres.2008.02.022

Pollutant Responses in Marine Organisms (PRIMO 14, Fourteenth

International Symposium on Pollutant Responses in Marine

Organisms (PRIMO 14)

(c) 2008 Elsevier Ltd All rights reserved.
Archimer

Archive Institutionnelle de l'Ifremer http://www.ifremer.fr/docelec/

\title{
Comet assay in phytoplankton as biomarker of genotoxic effects of environmental pollution
}

\author{
F. Akcha ${ }^{a}{ }^{*}$, G. Arzul $^{a}$, S. Rousseau ${ }^{a}$ and M. Bardouil ${ }^{b}$ \\ a IFREMER, Laboratoire d'Ecotoxicologie, Rue de l'lle d'Yeu, 44311 Nantes Cedex 03, France \\ b IFREMER, Laboratoire Phycotoxines, Rue de l'lle d'Yeu, 44311 Nantes Cedex 03, France \\ *: Corresponding author : F. Akcha, email adress : Farida.Akcha@ifremer.fr
}

\begin{abstract}
:
The alkaline comet assay was tested on different microalgae: the dinoflagellates, Karenia mikimotoi and Alexandrium minutum, and the diatom, Chaetoceros gracilis. The microalgae were exposed during their exponential growth to the model direct genotoxicant, hydrogen peroxide $(1 \mathrm{~h}, 5$ and $100 \mu \mathrm{M} \mathrm{H} \mathrm{H}_{2} \mathrm{O}_{2}$ ). Following $\mathrm{H}_{2} \mathrm{O}_{2}$ exposure, the comet assay was validated only for $\mathrm{K}$. mikimotoi for which genotoxicity was observed from the lowest tested concentration of $5 \mu \mathrm{M}$ with a concentrationdependent effect. $C$. gracilis was too small in size $(4 \mu \mathrm{m})$ to be correctly analysed. For $A$. minutum, our lysis buffer was not strong enough to digest the cellulosic thecal plates. For K. mikimotoi, the comet assay was thus applied for the study of the genotoxic effects of different pesticides: epoxiconazole (as Opus formulation), chlorpyriphos-ethyl (as Dursban formulation) and endosulfan at 1, 10 and $100 \mu \mathrm{g}$ of active substance/L for $24 \mathrm{~h}$. Exposure to epoxiconazole in formulation resulted in an increase in the extent of DNA strand breaks at the highest tested concentration of $100 \mu \mathrm{g} / \mathrm{L}$. Genotoxicity was also observed for chlorpyriphos-ethyl in formulation from $1 \mu \mathrm{g} / \mathrm{L}(p<0.05)$, with a significant increase at $10 \mu \mathrm{g} / \mathrm{L}$. Endosulfan exposure resulted in DNA damage for $K$. mikimotoi nuclei. Genotoxicity was observed from $1 \mu \mathrm{g} / \mathrm{L}$ of endosulfan and was not concentration dependent.
\end{abstract}

Keywords: Phytoplankton; Pesticides; Genotoxicity; Comet assay 
The phytoplankton is a model of choice for the study of the long term effects of pollutant exposure at population level. As primary producers, phytoplankton constitutes the first level of marine trophic chains. Due to its microscopic size, it is possible to get sample at population and community levels. Some species can be cultivated in photobioreactors under controlled conditions. Due to a high growth rate, phytoplankton offers the possibility to study the trans-generational effects of pollutant exposure. With a view to obtaining a better insight into the long term consequences of genotoxicity at population level, it appeared so valuable in a first step to test our alkaline comet assay on different microalgae. Up to now, most of the genotoxicity studies conducted in microalgae focussed on the formation of cyclobutane pyrimidine dimers, a DNA damage typical from UV irradiation (Fafandel et al., 2001, Häder et al., 2005).

For the exposure experiment, each phytoplankton strain [Karenia mikimotoi (GATIN95) isolated in 1995 in the bay of Brest, France; Alexandrium minutum (AM89BM) isolated in 1989 during a bloom in the Morlaix river, Brittany, France; Chaetoceros gracilis was obtained from SATMAR, Saint-Vaast-La Hougue, France] was cultivated in $\mathrm{f} / 2$ medium (Guillard and Ryther, 1962) at a temperature of $18^{\circ} \mathrm{C}$ and under controlled light $\left(60 \mu \mathrm{mol}\right.$ quanta/h/ $\left./ \mathrm{cm}^{2}\right)$.

The microalgae were exposed during their exponential growth (concentration of about $50 \times 10^{6} \mathrm{cells} / \mathrm{L}$ ) to hydrogen peroxide ( $1 \mathrm{~h}, 5$ and $100 \mu \mathrm{M}$ ), a model direct genotoxicant, and to different pesticides: epoxiconazole (as Opus ${ }^{\circledR}$ formulation form BASF), chlorpyriphos-ethyl (as Dursban ${ }^{\circledR}$ formulation from Dow AgroSciences) and endosulfan (in $0.01 \%$ DMSO) at 1,10 and $100 \mu \mathrm{g}$ of active substance/L for $24 \mathrm{~h}$ exposure. The toxicity of these compounds was previously demonstrated for several strains of phytoplankton (unpublished data): for epoxiconazole and chlorpyriphos-ethyl, the effective concentration (EC50) obtained was lower when the active substance was tested in formulation.

Following exposure, the cell suspension was concentrated by centrifugation at $300 \mathrm{~g}$ for $10 \mathrm{~min}$ and pellet was resuspended in $50 \mu \mathrm{L}$ of filtrated seawater. Cell viability was assessed under the microscope by a neutral red viability test. The comet assay was then carried out as described previously in Akcha et al. (2003) by using $30 \mu \mathrm{L}$ of the concentrated cell suspension. For each sample, two slides were prepared and the comet parameter Olive Tail Moment (OTM) of 150 cells was calculated using an image analysis system (Komet 4, Kinetic Imaging Ltd).

Following exposure, cell viability was at least $75 \%$ allowing the conduction of the comet assay. Comet data were normalised ( $\operatorname{Ln} \mathrm{x}$ ) and analysed by an ANOVA (Statistica 6.0 Soft.), taking exposure concentration as a random factor.

Following $\mathrm{H}_{2} \mathrm{O}_{2}$ exposure, a significant dose-dependent increase in comet parameters was observed only for $K$. mikimotoi nuclei $(p<0.005)$ (Figure 1 ), validating the use of the comet assay for genotoxicity study in this microalgal specie. C. gracilis nuclei was too small in size $(4 \mu \mathrm{m})$ to be correctly scored by our image analysis system. It is noteworthy that an application of the comet assay was already reported for another genus of this specie, C. tenuissimus (3-5 $\mu \mathrm{m})$, following cadmium exposure but damage was not assessed with the image software but by counting the number of comet cells against total normal cells (Desai et al., 2006). For A. minutum, our lysis buffer was not strong enough to digest the cellulosic thecal plates.

Epoxiconazole in formulation was genotoxic for $K$. mikimotoi only at the highest tested concentration of $100 \mu \mathrm{g} / \mathrm{L}$. DNA damage was also induced by chlorpyriphos-ethyl in formulation from the lowest tested concentration of $1 \mu \mathrm{g} / \mathrm{L}(\mathrm{p}<0.05)$, with a significant increase at $10 \mu \mathrm{g} / \mathrm{L}$. Endosulfan exposure resulted in DNA strand breaks from the concentration of $1 \mu \mathrm{g} / \mathrm{L}(p<0.05)$, but effect did not appear to be concentration-dependent. Effective concentrations for chlorpyrifos-ethyl (Auby, personal communication) and endosulfan (Nwankwoala and Osibanjo, 1992; Leonard et al., 2001, ) correspond to the higher concentrations recorded in the aquatic environment.

These results demonstrate the ability of $K$. mikimotoi to bioactivate the selected pesticides to reactive species for the DNA. Bioactivation of organic contaminants into genotoxic metabolites was already demonstrated by the SOS chromotest and by the comet assay for freshwater and marine green algae, Selenastrum capricornutum (Harwood et al., 1989) and Euglena gracilis, respectively (Aoyama et al., 2003). Despite the ability of microalgae to repair DNA strand breaks (Desai et al., 2006), genotoxic insult can have long term consequences on algal growth and diversity.

The applicability of the comet assay on phytoplankton offers valuable perspectives to study 1) the genotoxic effects of pollutants at population level, 2) the trans-generational effects of genotoxicant exposure and 3 ) the effects of genotoxicity on population genetics. 


\section{Acknowledgements}

This project was supported by IFREMER (French Institute for Exploitation of the Sea) and by The French Ministère de l'Ecologie et du Développement Durable.

\section{References}

Akcha, F., Vincent-Hubert, F., Pfohl-Leszkowicz, A. (2003). Mutat. Res., 534, 21-32.

Aoyama, K., Iwahori, K., Miyata, N. (2003). Mutat. Res., 538, 155-162.

Desai, S. R., Verlecar X. N., Goswami U. (2006). Ecotoxicol., 15, 359-363.

Fafandel, M., Bihari, N., Krajcar, V., Müller, W. E. G., Zahn, R. K., Batel, R. (2001). The Sci. Total Environ., 277, 149-159.

Guillard, R. R. L. and Ryther, J. H. (1962). Can. J. Microbiol., 8, 229-239.

Häder, D.-P. and Sinha, R. P. (2005). Mutat. Res., 221-233.

Harwood, M., Blaise, C., Couture P. (1989). Aquat. Toxicol., 14, 263-276.

Nwankwoala, A. U. and Osibanjo, O. (1992). Sci. Total Environ., 119, 179-190. 


\section{Figures}

Figure 1 : Effect of $\mathrm{H}_{2} \mathrm{O}_{2}$ exposure on the DNA fragmentation level of $K$. mikimotoi nuclei

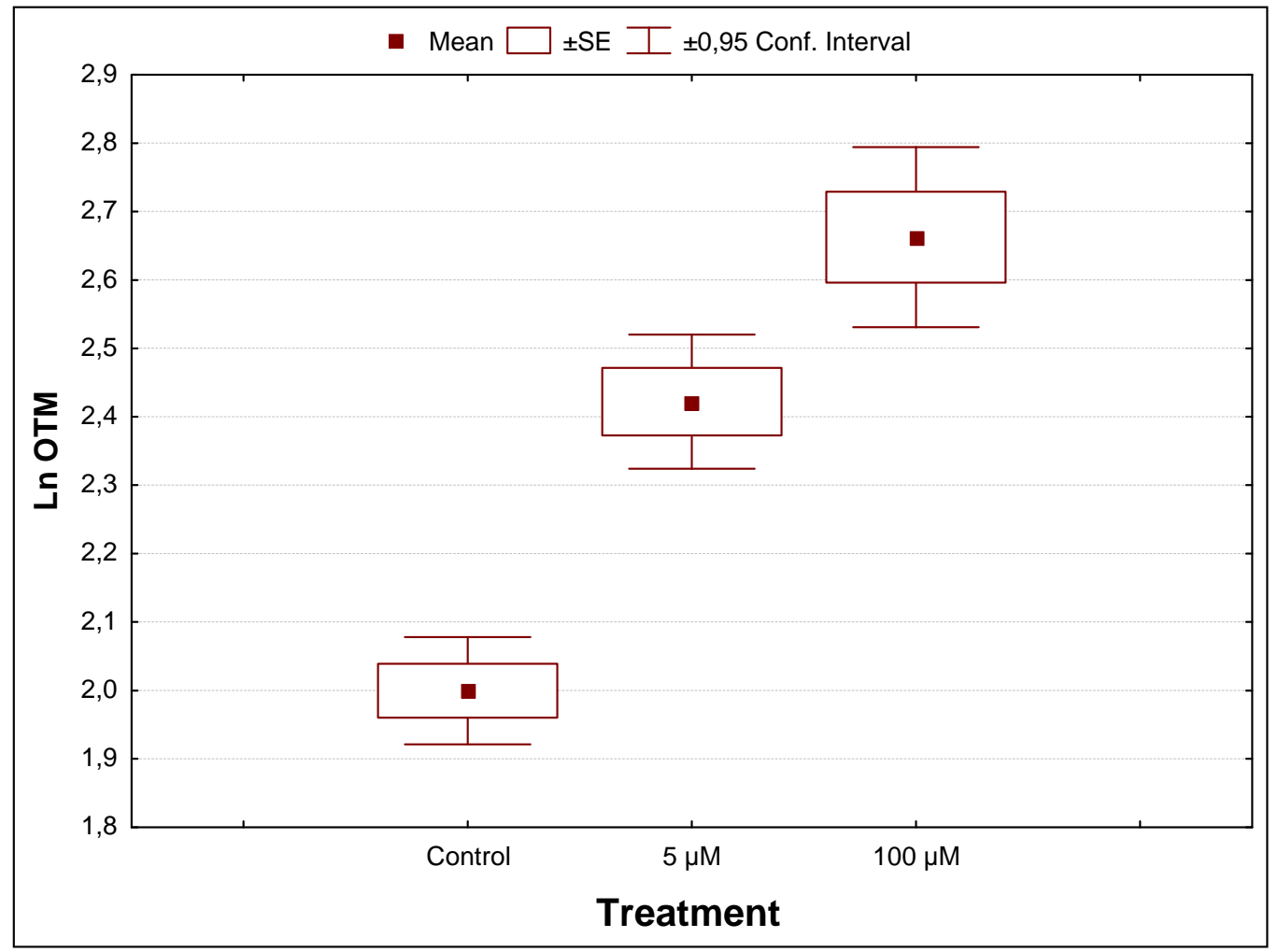


Figure 2: Effect of epoxiconazole in formulation (A), chlorpyriphos-ethyl in formulation (B) and endosulfan (C) exposure on the extent of DNA strand breaks of Karenia mikimotoi
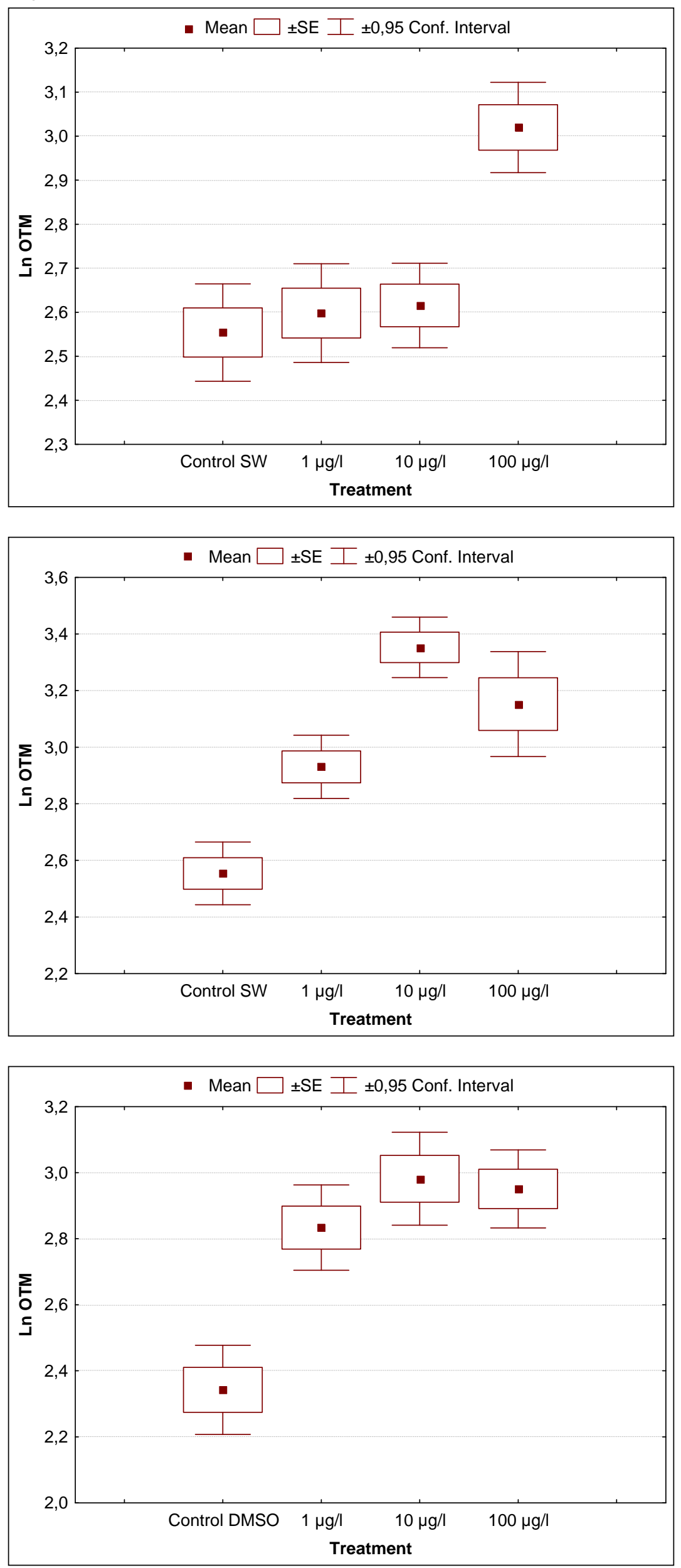